SARAH DENTON

\title{
TAX PLANNING IN THE BOARDROOM: SHOULD DIRECTORS OWE A DUTY TO UNDERSTAND THEIR COMPANIES' TAX PLANNING?
}

LLM RESEARCH PAPER

LAWS 516: TAXATION

FACULTY OF LAW

TE WHARE WĀNANGA O TE ŨPOKO O TE IKA A MĀUI

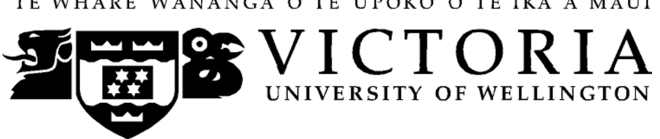

2013 


\section{Abstract}

This paper analyses whether directors should owe a duty to understand their companies' tax planning, and if so, what this duty should look like and whether this duty could successfully be implemented into New Zealand law. This paper then assesses whether it is in fact appropriate to impose on directors a duty to understand tax planning by comparing this duty to directors' obligations and liabilities in other areas of regulation. Finally, this paper concludes that directors should owe a duty to understand their companies' tax planning, but that this duty would be difficult to implement into New Zealand law.

\section{Word length}

The text of this paper (excluding abstract, table of contents, footnotes and bibliography) comprises approximately 14,511 words.

\section{Key words}

Directors' duties; tax planning; duty of care. 


\section{Contents}

I Introduction ..............................................................................

II Why Should Directors be Required to Understand Tax

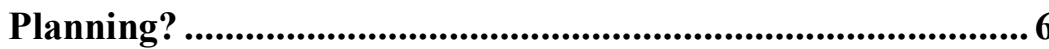

A The Directors' Role and Relationship With Their Companies .........................................................................6 6

B Tax Planning is An Important Matter to Companies........ 7

C Directors Make Decisions About Their Companies' Tax Planning ........................................................................ 11

D Increases Directors' Accountability For Their Companies'

Tax Planning

III How Could a Duty to Understand Tax Planning be Implemented?

A Does This Duty Fit Within One Of the Existing Statutory

Directors' Duties? ....................................................................... 13

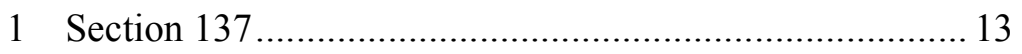

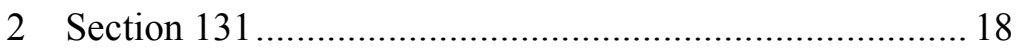

3 Enforcement of the statutory directors' duties ................. 21

B Would Parliament Enact a Separate Duty to Understand Tax

Planning? ................................................................................... 22

1 How should the duty be enforced? ................................. 22

2 Who should the duty be owed to? .................................... 24

3 What should be the scope of the duty? ............................ 24

4 What is the likelihood that Parliament would enact such a duty?

IV Is it Appropriate to Impose on Directors a Duty to Understand Tax Planning?.

A Is it Reasonable to Expect Directors to Understand their Companies' Tax Planning?

B Is a Duty to Understand Tax Planning Consistent with Directors' Obligations and Liability in Other Areas of Regulation?

1 Is the nature of this duty consistent with the nature of the existing statutory directors' duties? .

2 Is the liability imposed on directors for breaching this duty is consistent with the liability imposed on directors in other areas of regulation? 
3 Is the size of the directors' liability for breaching a duty to understand tax planning consistent with the size of the directors' liability for breaching other obligations? 42

C Are there Mechanisms in Place to Ensure that Directors Understand their Companies' Tax Planning? ...................... 43

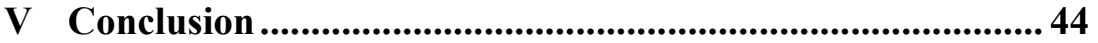




\section{Introduction}

The nature of directors' responsibilities in regard to their companies' tax planning has been the subject of much discussion and debate. This discussion has focused both on outlining what is expected of directors in regard to their companies' tax strategies and, more generally, on encouraging directors to take responsibility for their companies' approach in the tax sphere. ${ }^{1}$ For example, the Director of the Centre for Tax Policy and Administration at the Organisation for Economic Co-operation and Development (OECD) has noted that there is "an issue of the Board's responsibility to assess the financial and reputation risks associated with any particular tax strategy."2 The OECD has suggested that directors, when reviewing tax planning strategies, should "understand the major tax issues and their implications, establish reporting procedures, oversee taxes paid, and are aware of the tax jurisdictions and laws in which the company operates." "3 Tax authorities have also expressed their opinions on what they expect of directors. For example, the Australian Commissioner of Taxation has encouraged directors to recognise the need for a tax management strategy as part of their companies' governance frameworks, ${ }^{4}$ and the Inland Revenue Department (IRD) has commented that, "we don't expect directors and senior managers to be tax experts, but there are some issues they may want to focus on."5

These comments demonstrate that there is an expectation that directors will focus on and take responsibility for their companies' tax planning. The difficulty, however, is that this expectation is not binding on directors. That is, this expectation does not create an enforceable legal obligation on the part of directors in regard to their companies' tax planning. This paper will therefore look at whether directors should owe legal duties in regard to their companies' tax planning. Specifically, this paper will look at whether directors should owe a duty to understand their companies' tax planning, and if so, what this duty should look like and whether this duty could

\footnotetext{
${ }^{1}$ David Patterson "Tax Governance - Practitioners advising Boards and Audit and Risk SubCommittees" (paper presented to New Zealand Law Society - Tax Conference, September 2011) 65 at 67.

2 Jeffrey Owens "Good Corporate Governance: The Tax Dimension" in Wolfgang Schon (ed) Tax and Corporate Governance (Springer, 2008) 9 at 10.

${ }^{3}$ OECD Forum on tax administration - Information Note, General Administrative Principles: Corporate governance and tax risk management (July 2009) at 10.

${ }^{4}$ Michael D'Ascenzo, Commissioner of Taxation "What's tax got to do with it?" (speech to the Australian Institute of Company Directors, Sydney, 16 February, 2010).

${ }^{5}$ Inland Revenue Department Compliance Focus 2010-2011 (August 2010) at 25.
} 
successfully be implemented into New Zealand law. A duty to understand tax planning would help ensure that directors focus on and take responsibility for their companies' tax planning because it would both ensure that directors are better informed about their companies' tax planning and provide a mechanism to make directors accountable for their companies' tax planning when they breach this duty by failing to understand this tax planning.

This paper is structured into three main parts. Part 2 evaluates whether directors should owe a duty to understand tax planning. This part briefly sets out both the directors' role and the directors' relationship with their companies and then looks at the importance of tax planning to companies and the nature of directors' involvement in their companies' tax planning. Part 3 then examines how a duty to understand tax planning could be implemented. This part identifies two possible avenues for implementing this duty, namely: by fitting this duty within one of the existing directors' duties in the Companies Act 1993; or alternatively by Parliament enacting a separate statutory duty. Part 4 looks at whether it is appropriate to have a duty that requires directors to understand their companies' tax planning. This part evaluates the appropriateness of the duty by considering the reasonableness of this duty and comparing it to directors' obligations and liability in other areas of regulation. Part 5 then sets out the conclusions.

\section{Why Should Directors be Required to Understand Tax Planning?}

This part of the paper identifies three reasons why directors should be required to understand their companies' tax planning, namely: tax planning is an important matter to companies; directors make decisions about their companies' tax planning; and finally requiring directors to understand tax planning increases directors' accountability for their companies' tax planning.

\section{A The Directors' Role and Relationship With Their Companies}

It is important to appreciate the directors' role and relationship with their companies before looking at the reasons why directors should be required to understand their companies' tax planning. It is important to appreciate the directors' role and relationship because it explains 
both why directors make decisions about their companies' tax planning and why the directors companies' and these companies' shareholders might be interested in ensuring that directors understand tax planning.

Companies are required to appoint at least one director. ${ }^{6}$ The director or directors of the company act as a board of directors, ${ }^{7}$ and as a board, is responsible for managing, or supervising the management of, the business and affairs of the company. ${ }^{8}$ This responsibility to manage the business and affairs of the company is exercised on behalf of the company's shareholders. The company's shareholders hold one or more shares in the company ${ }^{9}$ and are therefore the owners of the company. The company's directors are thus accountable to the shareholders for the management of the company's property. ${ }^{10}$

The directors' relationship with their companies highlights that there is a separation between the people that manage the company (the directors) and the people that own the company (the shareholders). This separation explains why shareholders might be interested in ensuring that the directors of their companies understand their companies' tax planning. The directors' role also highlights that directors can confer the management of the company on persons other than the directors. This means that there might in some situations be a distinction between the company's directors and management. This distinction might affect who is responsible for making decisions about tax planning.

\section{B Tax Planning is An Important Matter to Companies}

Tax planning is a sufficiently important matter to companies to require directors to understand it. Tax planning is important to companies for a number of reasons. First, tax planning can have a significant impact on a company's profits. It both makes up a significant portion of a company's before-tax profits (for example, the basic income tax rate for companies in New Zealand is 28 per cent on

${ }^{6}$ Companies Act 1993, s 10(d).

${ }^{7}$ Section 127.

${ }^{8}$ Section 128 .

${ }^{9}$ Section 96.

${ }^{10}$ Andrew Beck and others Morison's Company Law (looseleaf ed, LexisNexis) at [23.1]. 
each dollar of the company's taxable income ${ }^{11}$ ) and can be used to manipulate the size of the company's after-tax profits.

Companies are able to arrange their financial affairs so as to minimise their tax obligations because income tax law suffers from ectopia. ${ }^{12}$ This problem is unique to income tax law. Ectopia refers to the dislocation between income tax law and the economic gains that are its target. ${ }^{13}$ These economic gains exist naturally and independently of income tax law. ${ }^{14}$ Income tax law taxes some of these gains, but not all of them. ${ }^{15}$ Therefore, income tax law has rules and categories to define what gains are taxed. An example of a rule is that countries place geographical limits on the gains that they tax. ${ }^{16}$ Another example is that income tax law divides these gains into segments by reference to time. ${ }^{17}$ The time period chosen is invariably 12 months. ${ }^{18}$ The consequence of the ectopic nature of income tax law is that it is impossible to construct a perfect income tax system. ${ }^{19}$ That is, the income tax system fails to tax all gains that Parliament intended should be taxed. ${ }^{20}$ There remain gains (which Parliament intended should be captured) that cannot adequately be captured by the income tax law. ${ }^{21}$ The incompleteness of the tax system, and in particular the rules which are used to distinguish gains that are taxed from gains that are not taxed, provides opportunities for taxpayers to arrange their financial affairs in a manner so as to minimise their tax obligations.

Westpac Banking Corporation Ltd $v$ Commissioner of Inland Revenue $^{22}$ provides an example that illustrates how tax planning can be used to manipulate the size of the company's profits. In this case, Westpac used its tax planning to influence its reported after-tax profits. This case concerned several structured financing transactions

\footnotetext{
${ }^{11}$ Income Tax Act 2007, sch 1, cl 2.

12 John Prebble "Ectopia, Formalism, and Anti-Avoidance Rules in Income Tax Law" in W. Krawietz and others (eds) Prescriptive Formality and Normative Rationality in Modern Legal Systems (Duncker and Humblot, 1994) 367 at 379.

${ }_{13}^{3}$ John Prebble "Ectopia, Tax Law and International Taxation" (1997) 5 B.T.R. 383 at 383.

${ }^{14}$ Kevin Holmes The Concept of Income: A multi-disciplinary analysis (IBFD Publications, Amsterdam, 2001) at 237.

${ }^{15}$ Above n 12, at 384 .

${ }^{16}$ At 385 .

${ }^{17}$ At 375 .

${ }^{18}$ At 375 .

${ }^{19}$ At 380 .

${ }^{20}$ At 382 .

${ }^{21}$ At 381 .

${ }^{22}$ Westpac Banking Corporation Ltd v Commissioner of Inland Revenue [2008] 2 NZLR 709 (HC).
} 
that Westpac had entered into. These transactions utilised either the conduit tax regime or the foreign tax credit regime in the Income Tax Act 2007. These transactions could potentially reduce Westpac's reported tax expense. This is because Westpac was entitled to claim deductions for its expenses in relation to these transactions but did not have to pay income tax on these transactions (because the income was exempt income). Westpac was able to manipulate and optimise its effective tax rate through its tax planning. Westpac's effective tax rate is the ratio of its accounting tax expense to its before-tax net profits (prepared for financial reporting purposes on a group basis). It measures the amount of tax that Westpac pays as a percentage of its reported before-tax net profits. ${ }^{23}$ Thus, the lower Westpac's effective tax rate, the higher its reported after-tax net profit. Westpac's annual target was an effective tax rate ranging between 20 per cent and 30 per cent, which Westpac believed was broadly in line with its competitors and other major corporates. ${ }^{24}$ Notwithstanding, Westpac's management progressively allowed the effective tax rate to fall ${ }^{25}$ and the growth of these transactions caused a steady decline in Westpac's effective tax rate. $^{26}$ This continued to the point that Westpac was recommended to pay NZD 30,000,000 to NZD 40,000,000 in tax, even though that sum represented an effective tax rate of only 6.5 per cent against the bank's reported profit. ${ }^{27}$

Tax planning can also have an impact on the share value of listed companies. This is because tax planning can have an impact on the size of the dividends that companies will distribute to its shareholders. If tax planning is used to influence a company's profits, then this will impact on how much profit is available to the company to distribute to its shareholders as dividends. If the company maintains its share value by paying regular dividends to shareholders and these dividends are different to what was expected then this might have an impact on the company's share value.

Furthermore, a company's tax planning can harm the company's reputation. This risk was identified in the Westpac case. Harrison J noted on several occasions in his judgment that Westpac's management acknowledged the reputational risk associated with

${ }^{23}$ Westpac, above n 22, at [88].

${ }^{24}$ At [88].

${ }^{25}$ At [554].

${ }^{26}$ At [555].

${ }^{27}$ At [564]. 
Westpac's tax policies. His Honour noted that, "consideration of 'reputational risk' was always at the forefront of [the Westpac] group tax policies." ${ }^{28}$ His Honour then noted that: ${ }^{29}$

Mr Mataira [Westpac's head of New Zealand group tax] well understood the elements of the Koch transaction. He believed that they accorded with Westpac group's tax policy; that they complied with all legal requirements; and that they did not 'threaten the [b]ank's reputation as a good corporate citizen'.

\section{Harrison $\mathrm{J}$ also noted that: ${ }^{30}$}

Westpac was always conscious of its [effective tax rate]. The bank was anxious not to reduce it unduly because of its reputational effect; it wanted to appear as a good corporate citizen paying a responsible level of tax. For that reason, Westpac's chief executive officer imposed a minimum [effective tax rate] for the Westpac group of 25\% in 1997.

It appears that Starbucks also recognised the impact that its tax planning had on its corporate image. This is illustrated by the fact that Starbucks said that it would pay $£ 10,000,000$ of United Kingdom corporation $\operatorname{tax}^{31}$ in response to criticism that it had been avoiding paying tax in the United Kingdom. ${ }^{32}$ Starbucks said in a statement that: ${ }^{33}$

[W] listened to our customers in December and so decided to forgo certain deductions which would make us liable to pay 10 million pounds in corporation tax this year and a further 10 million pounds in 2014.

Finally, a company's tax planning can have an impact on the likelihood that the IRD will find an issue with the company's tax position and challenge that position. If the IRD finds that the company has filed an incorrect tax position then the company can be

\footnotetext{
${ }^{28}$ Westpac, above $\mathrm{n} 22$, at [86].

${ }^{29}$ At [109].

${ }^{30}$ At [554].

${ }^{31}$ Kamal Ahmed "Starbucks pays first tax since 2008" The Telegraph (online ed, Kent, 22 June 2013).

32 Terry Macalister "Starbucks pays corporation tax in UK for first time in five years" The Guardian (online ed, London, 23 June 2013).

${ }^{33}$ Macalister, above $\mathrm{n} 32$.
} 
exposed to financial consequences such as use of money interest and shortfall penalties.

\section{Directors Make Decisions About Their Companies' Tax Planning}

There is evidence that directors make decisions about their companies' tax planning. Directors are encouraged to focus on tax issues $^{34}$ and the board is generally responsible for a company's tax strategy and overseeing its implementation. ${ }^{35}$ Directors also actively review and approve their companies' tax planning. Freedman, Loomer and Vella looked at the findings of a United Kingdom survey of tax directors conducted in the first half of $2008 .{ }^{36}$ The authors noted that a majority of the interviewees' companies had a tax policy or tax strategy and almost all of these policies or strategies were approved by their companies' board of directors. ${ }^{37}$ The authors also noted that a majority of the interviewees said that their companies' board (or board committee) is involved at some stage in the decisionmaking or review processes relating to these tax policies or strategies. $^{38}$

Directors should be required to understand their companies' tax planning because they make decisions about this tax planning. Directors need to understand tax planning to be able to properly contribute to these decisions. Directors would be able to properly contribute because they would be better informed about the tax planning. This argument is supported by Miller J's comments in Davidson $v$ Registrar of Companies ${ }^{39}$ about what knowledge is required of directors of finance companies. This case is one of several cases that resulted from the collapse of several finance companies in New Zealand between 2007 and 2008. The Financial Markets Authority (and before 1 May 2011, the Securities Commission) and Serious Fraud Office launched investigations into these failed companies and this resulted in charges being laid against the directors and officers of several of these companies. Miller J stated that: ${ }^{40}$

\footnotetext{
${ }^{34}$ Above $\mathrm{n} 5$, at 25 .

${ }^{35}$ Above $\mathrm{n} 1$, at 65.

${ }^{36}$ Judith Freedman and others "Corporate Tax Risk and Tax Avoidance: New Approaches" (2009) 1 B.T.R. 74 at 84.

${ }^{37}$ At 84 .

${ }^{38}$ At 85 .

${ }^{39}$ Davidson v Registrar of Companies [2011] 1 NZLR 542 (HC).

${ }^{40}$ Davidson, above n 39, at [121].
} 
[A] degree of financial literacy is required of any director of a finance company. Without it, Mr Davidson could scarcely understand the business, let alone contribute to policy decisions affecting risk management and monitor the company's performance...

Though Miller J's comment relates specifically to the directors of finance companies, this comment can also be construed more generally. The general proposition here is that directors need a degree of knowledge about the activities that their companies' partake in, in order to be able to both understand their companies' businesses and contribute to their companies' policy decisions. In this case, this means that directors of finance companies need a degree of financial literacy to be able to both contribute to their companies' policy decisions and properly monitor their companies' affairs. In the case of companies that engage in tax planning, this means that directors need to understand their companies' tax planning to be able to contribute to their companies' policy decisions about this tax planning.

\section{Increases Directors' Accountability For Their Companies' Tax Planning}

If there is no legal requirement that directors understand their companies' tax planning then there might be no repercussions for a director that fails to understand this tax planning. Therefore, requiring directors to understand their companies' tax planning would increase their accountability for this tax planning because it would provide a legal mechanism to make directors responsible for when they fail to understand this tax planning. That is, requiring directors to understand this tax planning imposes on directors an enforceable obligation in regard to their companies' tax planning.

\section{How Could a Duty to Understand Tax Planning be Implemented?}

Part 2 of this paper established that directors should be required to understand their companies' tax planning. To give this requirement legal standing it needs to be implemented into law. This part of the paper therefore examines how a duty to understand tax planning could be implemented into law by looking at whether this duty could fit 
within one of the existing directors' duties in the Companies Act, or alternatively, whether Parliament would enact a separate statutory duty to understand tax planning.

\section{A Does This Duty Fit Within One Of the Existing Statutory Directors' Duties?}

For simplicity, this part of the paper focuses only on the statutory directors' duties in New Zealand. In New Zealand, there is no statutory directors' duty to understand the company's tax planning. Therefore, it is necessary to look whether this duty might fit within one of the existing directors' duties in the Companies Act. There are two possible statutory duties that this duty might fit within: the duty to act in good faith and in the best interests of the company (s 131) and the duty to exercise reasonable care, diligence and skill (s 137). In assessing whether this duty might fit within one, or both of these sections, it is necessary to consider the scope of these statutory duties and also the likelihood that a court would find that the duty to understand tax planning fits within one of these duties.

$1 \quad$ Section 137

Section 137 sets out that: ${ }^{41}$

A director of a company, when exercising powers or performing duties as a director, must exercise the care, diligence, and skill that a reasonable director would exercise in the same circumstances taking into account, but without limitation,-

(a) the nature of the company; and

(b) the nature of the decision; and

(c) the position of the director and the nature of the responsibilities undertaken by him or her.

Section 137 establishes a statutory duty of care. The standard of care expected of directors is based on the reasonable director. Thus, the director's knowledge and experience is not relevant. ${ }^{42}$ However, this section provides that in assessing whether the standard of care has been met the court may take into account the nature of the company, the nature of the decision, and the position of the director and the nature of responsibilities undertaken. This introduces an element of

\footnotetext{
${ }^{41}$ Companies Act, s 137.

${ }^{42}$ Brookers Company Law (online looseleaf ed, Thomson Reuters) at [CA137.01].
} 
subjectivity to the assessment. Therefore, the court would look at a reasonable director in the particular circumstances of the case. ${ }^{43}$

There are several reasons to indicate that a court would consider reading the standard of care expected of directors as including a requirement that directors understand their companies' tax planning. First, the interpretation of the standard of care expected of directors is arguably broad enough to include a requirement that directors understand their companies' tax planning. For example, the New South Wales Court of Appeal, in a leading case on the director's duty of care, Daniels $v$ AWA Ltd, proposed that the minimum standard of care expected of all directors requires that directors, among other things, acquire a basic understanding of the business of the company, be familiar with the fundamentals of the company's business, ${ }^{44}$ and are under a continuing obligation to keep informed about the activities of the company. ${ }^{45}$ It is arguable that a requirement that directors acquire a basic understanding of the business of the company is broad enough to include a requirement that directors understand the tax planning of the company. Though the expression "the business of the company" might on its face appear to refer primarily to the company's operations or trading activities (for example, a bank's operations is to offer financial products, services, and advice to businesses and individuals) it is arguable that this expression also refers to the company's tax planning. This is so because tax planning is inextricably linked to the company's operations. Tax planning is a necessary consequence of the company's operations: it arises out of a company's obligation to pay tax, and this obligation to pay tax arises when a company engages in profitable activities. That is, there will always be some kind of tax planning if a company's trading activities are profitable and so the company has an obligation to pay tax. Therefore, tax planning should also be considered part of the "business of the company" because it is so entwined in the company's operations.

This argument is also supported by the fact that the similar expression "the business of the company and its affairs" used in s 128 of the Companies Act includes both the company's trading activities, and also the company's internal and administrative management

${ }^{43}$ Brookers, above n 42, at [CA137.01].

${ }^{44}$ Daniels v AWA Ltd (1995) 37 NSWLR 438 (CA) at 61.

${ }^{45}$ At 61 . 
decisions. ${ }^{46}$ It thus follows that the expression "the business of the company" used by the New South Wales Court of Appeal should also refer to both the company's trading activities and the company's internal or administrative activities. Tax planning is an example of an internal or administrative activity.

Furthermore, the fact that the construction of s 137 means that the standard of care expected of directors depends on, among other things, the nature of the decision and the nature of the responsibilities undertaken, ${ }^{47}$ suggests that if directors are making decisions in regard to their companies' tax planning, then a court would, taking into account the nature of these decisions, expect that these directors, in exercising the care, diligence, and skill that a reasonable director would exercise in the same circumstances, understand their companies' tax planning. This argument is supported by Miller J's comment in Davidson (this comment was referred to earlier in this paper but is stated again for ease of reference) that: ${ }^{48}$

[A] degree of financial literacy is required of any director of a finance company. Without it, Mr Davidson could scarcely understand the business, let alone contribute to policy decisions affecting risk management and monitor the company's performance...

Miller J's comment illustrates that the standard of care expected of directors requires that directors understand the particular aspects of their companies that they are involved in and make decisions about. To apply this comment to tax planning, this means that directors that are involved in, and make decisions about, their companies tax planning need to understand that tax planning to meet the standard of care expected of them.

However, there is a difficulty in trying to apply s 137 to tax planning. This difficulty undermines the likelihood that a court would read the standard of care expected of directors as including a requirement that directors understand their companies' tax planning. This difficulty relates to the fact that the standard of care expected of directors flows from the directors' powers and duties. There are two parts to the duty of care in s 137: directors must first be exercising

${ }^{46}$ Brookers, above $\mathrm{n}$ 42, at [CA128.01].

${ }^{47}$ Companies Act, s 137.

${ }^{48}$ Davidson, above n 3940, at [121]. 
powers or performing duties as a director; and directors must then, when exercising these powers or performing these duties, exercise the care, diligence, and skill that a reasonable director would exercise in the same circumstances, taking into account the factors identified earlier in the paper. For example, directors are exercising powers as directors when they, acting as a board of directors, decide to issue new shares $^{49}$ or approve the buyback of the company's shares. ${ }^{50}$ In these examples, the directors are exercising powers that are prescribed to them by legislation. Ministry of Economic Development $v$ Feeney $(\text { Feltex })^{51}$ provides another example that illustrates how this duty operates. In this case, all five of Feltex Carpets Ltd's directors faced charges under s 36A of the Financial Reporting Act 1993 relating to the accuracy of Feltex Carpet's interim financial statements for the half year to 31 December 2005. Section 36A(1) of the Financial Reporting Act requires any statement by, or on behalf of a reporting entity that contains, inter alia, interim financial information for the reporting entity to comply with any applicable financial reporting standards. Judge Doogue held that when "dealing with a statement as referred to in [the Financial Reporting Act] s 36A, the director is exercising powers or performing duties as a director." 52 Therefore, it is appropriate to judge the conduct of directors by reference to what the Companies Act has to say how they may exercise powers and perform duties, ${ }^{53}$ including the standard of care set out in s 137 . Judge Doogue carefully articulated the relationship between the directors' obligations in the Financial Reporting Act and the provisions in the Companies Act about the directors' powers of management, their duties and how they may exercise powers and perform duties. The problem in applying the duty of care in s 137 to tax planning is that it is not clear whether directors, when making decisions about their companies' tax planning, are exercising powers or performing duties as a director. There is no statutory power enabling directors to make decisions about their companies' tax planning. There is also (unlike the Feltex case, where the directors had a statutory obligation to ensure that any statement prepared by, or on behalf of, the reporting entity that contains interim financial information for the reporting

\footnotetext{
${ }^{49}$ Companies Act, s 42.

${ }_{51}^{50}$ Companies Act, s 58.

${ }^{51}$ Ministry of Economic Development v Feeney (2010) 10 NZCLC 264,715 [Feltex].

${ }_{53}$ At [38].

${ }^{53}$ At [34].
} 
entity complies with this section $^{54}$ ) no statutory obligation that directors must make decisions about tax planning. Therefore, it is arguable that the first part of the duty of care in s 137, which requires that directors must be exercising powers or performing duties as a director, is not satisfied in respect of decisions about tax planning. This means that decisions about tax planning do not fall within the scope of s 137 and therefore the standard of care set out in this section does not apply to these decisions. The corollary is that even if the standard of care in s 137 includes a requirement that directors understand their companies' tax planning, this requirement could never be applied to decisions about tax planning. This would thus mean that it would be pointless to include in the standard of care expected of directors a requirement that directors understand tax planning. This is because this requirement could never be applied to decisions about tax planning, even though this is the exact kind of situation that this requirement ought to be applied to.

There are, however, two possible ways to mitigate this problem. First, companies could modify their constitutions to include a power enabling directors to make decisions about their companies' tax planning. This would mean that it is still helpful to include in the standard of care expected of directors a requirement that directors understand tax planning, because this requirement could in some situations be applied to decisions about tax planning, when the company has included in its constitution a power enabling its directors to make decisions about tax planning.

Secondly, it is arguable that s 128 is broad enough to include a power to make decisions about tax planning. This section gives the board of a company "all the powers necessary for managing, and for directing and supervising the management of, the business and affairs of the company." 55 The expression the "business and affairs of the company" includes both the company's trading activities and the company's internal and administrative management decisions. ${ }^{56}$ The expression is therefore broad enough to include the company's tax planning. This means that s 128 can be read as giving the board of a company all the powers necessary for managing, and for directing and supervising the management of, the company's tax planning. Thus, it

\footnotetext{
${ }_{55}^{54}$ Financial Reporting Act 1993, s 36(3)(a).

${ }^{55}$ Companies Act, s 128(2).

${ }^{56}$ Brookers, above n 42, at [CA128.01].
} 
is arguable that even though there is no express statutory provision giving directors' powers to make decisions about their companies' tax planning, s 128 is broad enough to give directors' powers to make decisions about tax planning.

For these reasons, there is a strong argument that a court would read the standard of care expected of directors in $\mathrm{s} 137$ as including a requirement that directors understand their companies' tax planning. This interpretation of the standard of care is supported by the fact that reading the standard of care to require directors to understand tax planning is consistent with what the standard of care already requires of directors. This interpretation is further supported by the fact that the standard of care can be applied to decisions about tax planning because s 128 indicates that when directors are making decisions about tax planning they exercising powers as directors.

In the case that a court would not read the standard of care expected of directors as including a requirement that directors understand their companies' tax planning, it is valuable to also look at whether the duty to understand tax planning might alternatively fit within s 131.

\section{$2 \quad$ Section 131}

Section 131 sets out that: ${ }^{57}$

...[A] director of a company, when exercising powers or performing duties, must act in good faith and in what the director believes to be the best interests of the company.

Directors have a duty to act in good faith and in what the director believes to be the best interests of the company. It is arguable that it is in the best interests of the company that the company's directors understand the company's tax planning. This is so because directors that understand this tax planning would be able to make better informed decisions about this tax planning. Directors that understand tax planning might change their attitudes towards their companies' tax planning, and consequently change their decisions about this tax planning. Directors that understand tax planning might therefore decide that their companies should adopt different tax planning strategies.

${ }^{57}$ Companies Act, s 131(1). 
However, this argument is not convincing for several reasons. First, it does not necessarily follow that directors who understand their companies' tax planning will make decisions that are in their companies' best interests. For example, directors who understand their companies' tax planning might decide that their companies should take a conservative tax position. Taking a conservative tax position will reduce the likelihood that the tax position is incorrect, and therefore reduce the likelihood that the IRD will find an issue with the tax position and challenge that position. This challenge could expose the companies to financial costs such as use of money interest and shortfall penalties. However, directors who understand their companies' tax planning might still decide that their companies should take an aggressive tax position. Taking an aggressive tax position will obviously increase the likelihood that the tax position is incorrect and will therefore be challenged by the IRD. Taking this position would thus increase exposure to these financial costs. This example demonstrates that directors who understand their companies' tax planning might still make decisions that expose their companies to increased financial costs, and are therefore not in the companies' best interests.

Secondly, even if directors decide that their companies should take a conservative tax position, this decision is not necessarily in their companies' best interests. Though this decision might reduce exposure to financial costs such as shortfall penalties, this decision also means that these companies will pay more tax than they would have otherwise paid if they had adopted a more aggressive tax position. Paying more tax is not in the company's best interests because it reduces the company's overall wealth, by reducing the company's after-tax profit. There is support for this argument that paying more tax is not in the company's best interests (that is, it is in the company's best interests to minimise the company's tax obligation). For example, in the Westpac case, Harrison J noted that it was "Mr Mataira's view that the best interests of the bank and its shareholders were to pay as little New Zealand tax as legitimately possible." 58 Furthermore, the Privy Council in Mangin $v$ Commissioner of Inland Revenue noted that: ${ }^{59}$

\footnotetext{
${ }_{58}^{58}$ Westpac, above $\mathrm{n} 22$, at [548].

${ }^{59}$ Mangin v Comissioner of Inland Revenue [1971] NZLR 591 (PC).
} 
If a bona fide business transaction can be carried through in two ways, one involving less liability to tax than the other, their Lordships do not think sec 108 can properly be invoked to declare the transaction wholly or partly void merely because the way involving less tax is chosen. Indeed, in the case of a company, it may be the duty of the directors vis a vis their shareholders to so act.

The High Court in Challenge Corporation Limited $v$ Commissioner of Inland Revenue quoted this statement, ${ }^{60}$ although this case was appealed to the Privy Council and the Privy Council did not refer to this statement. $^{61}$

Finally, although it has been appreciated that a company's tax planning can harm the company's reputation, ${ }^{62}$ it is not clear whether tax planning can harm the company's reputation in a way that is actually detrimental to the company's business. That is, the fact that the company's tax planning might risk, for example, harming the company's reputation or being found to be tax avoidance, does not necessarily mean that this tax planning is not in the company's best interests. This is demonstrated in the Westpac case. Harrison $\mathrm{J}$ held that Westpac had engaged in tax avoidance and upheld the IRD's assessment of Westpac's liability at NZD 586,000,000. Notwithstanding, this decision did not appear to have any material impact on Westpac's business. The decision did not impact Westpac's share value. ${ }^{63}$

This reasoning demonstrates that the company has competing interests in regard to its tax planning. That is, it is in the company's best interests to minimise the company's tax obligation but it is also in the company's best interests to reduce the company's exposure to the financial costs that are associated with filing an incorrect tax position. This means that any decision that the company's directors make in regard to the company's tax planning can be attacked as not being in the company's best interests.

Notwithstanding, it is still arguable that it is in the company's best interests that the company's directors understand the company's tax planning. This is so because, even though directors that understand

\footnotetext{
${ }^{60}$ Challenge Corporation Limited $v$ Commissioner of Inland Revenue (1984) 6 NZTC 62,808 (HC).

${ }^{61}$ Challenge Corporation Ltd v Commissioner of Inland Revenue [1986] 2 NZLR 513 (PC).

${ }^{62}$ Westpac, above $\mathrm{n} 22$, at [86].

${ }^{63}$ Niko Kloeten "Westpac loses $\$ 900$ million tax avoidance case" The National Business Review (online ed, New Zealand, 8 October 2009).
} 
tax planning are not able to make decisions about the tax planning that are in the company's best interests, directors that understand tax planning are able to make decisions about the tax planning that better balance these competing interests. That is, the directors would be able to make decisions that balance the company's interests to minimise its tax obligations against the company's interests to reduce the risk that the IRD will challenge its tax position, in a manner that is consistent with how the company would balance each of these interests.

Therefore, there is a strong argument that it is in the company's best interests that the company's directors understand the company's tax planning. For this reason, it is arguable that a duty to understand tax planning could also fit within s 131 .

\section{Enforcement of the statutory directors' duties}

The main problem with using the existing directors' duties in the Companies Act to implement a duty to understand tax planning concerns how these duties are enforced. Section 301 allows for a global enforcement of breaches of directors' duties. ${ }^{64}$ If in the course of liquidation the court finds that the director has breached a duty, the court has discretion to order that the director contribute to the company's assets by way of compensation as the court thinks just. ${ }^{65}$ It has been held that the appropriate method for assessing the amount of liability is to require that the director's liability to contribute to the assets of the company be neither more nor less than that director's just desserts. ${ }^{66}$ The problem with the approach to enforcing the directors' duties in the Companies Act is that these duties are generally only enforced when the company is insolvent. The company is only going to enforce these duties if doing so will benefit the company. Therefore, the company might bring a claim against the directors for breach of these duties when the company is insolvent because if the claim is successful, then the directors might be required to personally contribute to the company's assets by way of compensation, and this will increase the pool of assets available to distribute to the company's creditors and shareholders. But if the company is not insolvent, then there is no need to bring a claim against the directors for breach of duties because there has been no harm to the company.

\footnotetext{
${ }^{64}$ Re Cellar House Ltd (in liquidation) (2009) 15 NZBLQ 3 at [223].

${ }^{65}$ Companies Act, s 301.

${ }^{66}$ Nippon Express (New Zealand) Ltd $v$ Woodward \& Hutt (1998) 8 NZCLC 261,765 at [24]; and see also Fatupaito v Bates [2001] 3 NZLR 386 at [93].
} 
This is a problem because if directors breach the duty to understand tax planning, but there is no harm to the company as a result (for example, if the company does not become insolvent) then this breach might not be enforced. Therefore, if this duty was included within one of the existing directors' duties in the Companies Act, this duty would not always be enforced. This reduces the effectiveness of the duty at ensuring that directors understand their companies' tax planning because there is less likely to be consequences for breaching the duty. For this reason, even if the existing statutory directors' duties could be used to implement a duty to understand tax planning there is limited value to be gained from including it within one of these duties.

\section{B Would Parliament Enact a Separate Duty to Understand Tax Planning?}

The difficulties in trying to include a duty to understand tax planning within the existing statutory directors' duties, coupled with the limited value to be gained from doing so, indicate that it is not suitable to try to fit the duty to understand tax planning within the existing duties. Instead, it is more suitable to enact an express directors' duty to understand tax planning. This duty would be a separate duty that would sit alongside the existing statutory directors' duties. There is no directors' duty to understand tax planning either in New Zealand legislation or at common law. Therefore, Parliament would have to enact legislation to create a separate duty to understand tax planning. This duty could possibly be included either in the Companies Act, or alternatively in the Income Tax Act. This part of the paper evaluates whether Parliament would enact a separate directors' duty to understand tax planning. This part first looks at how this duty should be enforced, to whom this duty should be owed to, and what should be the scope of this duty. This part then considers the likelihood that Parliament would enact legislation to enact this duty.

$1 \quad$ How should the duty be enforced?

Like the approach to enforcing the directors' duties in the Companies Act, it is appropriate that directors should be personally liable to the company for breaching the duty to understand tax planning by failing to understand this tax planning. This will deter directors from failing to understand this tax planning in the future. 
However, this duty is only effective at ensuring that directors understand their companies' tax planning if it is enforced. The director's company will only enforce this duty against the director if there is some benefit to the company in doing so. Therefore, there needs to be a reason to enforce the duty. The company might enforce this duty if the company incurred a shortfall penalty for its tax position. Shortfall penalties can be imposed on the company for filing an incorrect tax position. The IRD can charge shortfall penalties on top of the company's normal tax obligation. The shortfall penalty is a percentage of the tax shortfall (deficit or understatement of tax), that results from certain actions by the employer. ${ }^{67}$ Shortfall penalties can be imposed for: lack of reasonable care (20 per cent); unacceptable tax position (20 per cent); gross carelessness (40 per cent); abusive tax position (100 per cent) and evasion (150 per cent). The extent of the shortfall penalty depends on the taxpayer's position. For example, the penalty payable for taking an abusive tax position is 100 per cent of the resulting tax shortfall. ${ }^{68}$ These penalties are a debt of the company that is owed to the IRD. Therefore, the company might bring a claim against the directors for breaching the duty to understand tax planning when the company has incurred a shortfall penalty because if the claim is successful, then the directors might be held personally liable for that penalty rather than the company. That is, if the claim is successful then the company can recover the cost of the penalty from the company's directors. To give an example, this would mean that if a director has breached this duty, and the director's company has taken an abusive tax position ${ }^{69}$ and as a result has incurred a shortfall penalty for taking that tax position, then the director could become personally liable for that penalty.

To permit this duty to be enforced if the company has incurred a shortfall penalty for its tax position also addresses one of the problems with using the existing statutory directors' duties to implement a duty to understand tax planning. This problem is that the existing statutory directors' duties are generally only enforced when the company is insolvent. To permit this duty to be enforced if the company has incurred a shortfall penalty addresses this problem because it means

\footnotetext{
${ }^{67}$ Inland Revenue Department Taxpayer obligations, interest and penalties (IR40, April 2013) at 25.

${ }^{68}$ Tax Administration Act 1994, s 141D(3).

${ }^{69}$ Section $141 \mathrm{D}(7)$.
} 
that this duty might be enforced in order to recover that shortfall penalty from the directors even if the company is still solvent after it has incurred this penalty. Thus, this duty might be enforced in situations other than when the company is insolvent.

$2 \quad$ Who should the duty be owed to?

The duty to understand the company's tax planning should be owed to the company. This is appropriate because a breach of this duty can harm the company, for example, if the company incurred a shortfall penalty for its tax position. This means that the company has a reason to enforce a breach of the duty so that the company can recover the cost of that penalty from the company's directors.

$3 \quad$ What should be the scope of the duty?

The scope of the duty to understand tax planning depends on the level of understanding of this tax planning that directors need to have to satisfy this duty. The case law on the director's duty of care provides some guidance on what level of understanding should be required of directors. For example, the NSW Court of Appeal in Daniels $v$ AWA $L t d$ required that a director acquire a basic understanding of the business of the company and be familiar with the fundamentals of the company's business. ${ }^{70}$ Similarly, Heath $\mathrm{J}$ in $R v$ Moses (Nathans Finance) stated that, "[f]or example, a director of a finance company should be expected to know that a "current asset" is one expected to be realised within one year."71 The example that the High Court used is very simple - most of the classifications and disclosures in a company's financial statements are more complicated than this. Therefore, these cases suggest that directors need only a basic level of understanding of the company's business (and in the case of finance company directors, of the company's financial statements) to satisfy the duty of care. It follows then that the level of understanding of tax planning that directors need to satisfy the duty to understand tax planning should be similar. That is, directors should only need to have a basic level of understanding of their companies' tax planning.

${ }^{70}$ Daniels $v$ AWA Ltd, above $\mathrm{n} 44$, at 61.

${ }^{71} R$ v Moses HC Auckland CRI-2009-004-1388, 8 July 2011 [Nathans Finance] at [83]. 
$4 \quad$ What is the likelihood that Parliament would enact such a

duty?

A duty to understand tax planning could only be implemented if Parliament decided to enact legislation to implement this duty. It is not clear whether Parliament would do this. Legislatures in other jurisdictions have been receptive to enacting legislation that expands the scope of directors' duties. That is, legislation that imposes obligations on directors that are more onerous than the prior obligations on directors. For example, the United Kingdom enacted a duty in its Companies Act 2006 that requires directors to have regard to matters including, among others, the interests of the company's employees, the need to foster the company's business relationships with suppliers, customers and others and the impact of the company's operations on the community and the environment. ${ }^{72}$ Section 172 sets out that: ${ }^{73}$

(1) A director of a company must act in the way he considers, in good faith, would be most likely to promote the success of the company for the benefit of its members as a whole, and in doing so have regard (amongst other matters) to-

(a) the likely consequences of any decision in the long term,

(b) the interests of the company's employees,

(c) the need to foster the company's business relationships with suppliers, customers and others,

(d) the impact of the company's operations on the community and the environment,

(e) the desirability of the company maintaining a reputation for high standards of business conduct, and

(f) the need to act fairly as between members of the company.

The directors' duty to understand their companies' tax planning also expands the scope of directors' duties because it requires directors to understand more of their companies' matters (that is, more than just their companies' trading activities). The introduction of s 172 demonstrates that legislatures have been willing to introduce similar duties. Therefore, the introduction of this section indicates that enacting legislation to implement a duty to understand the company's tax planning would not be out of line with the development of

${ }^{72}$ Companies Act 2006 (UK), s 172.

${ }^{73}$ Section 172. 
directors' duties in other jurisdictions. It also indicates that the New Zealand Parliament might be receptive to the idea of enacting legislation to implement this duty.

There is, however, evidence that suggests that Parliament would not be receptive to the idea of enacting legislation that would expand the scope of directors' duties. The Health and Safety in Employment Act 1992 does not impose any direct duties on either the board of directors or individual directors. The Royal Commission on the Pike River Coal Mine Tragedy suggested that the Health and Safety in Employment Act should be amended to include a statutory duty requiring directors to play their part at the governance level in ensuring that the company has an effective health and safety management system. ${ }^{74}$ (The Royal Commission did not however make a formal recommendation that such a duty be imposed). The Royal Commission described the section in the Health and Safety in Employment Act that deals with the liability of directors in relation to offences committed by their companies ${ }^{75}$ as ineffective ${ }^{76}$ because it requires that the director has actively participated in making decisions in relation to the circumstances resulting in the incident. The section is therefore less likely to catch the directors of larger companies, because these directors have normally delegated to executive management the operational decisions that give rise to breaches of health and safety. ${ }^{77}$ That is, these directors are more removed from the company's day-to-day operations, and therefore the company's incidents. It is thus clear from the Royal Commission's analysis that it wants to directly impose on the company's directors the responsibility for ensuring the company has a healthy and safe workplace. The Report of the Independent Task Force on Workplace Health and Safety also recommended that duties should extend to all those in governance roles. ${ }^{78}$ Notwithstanding, the government did not follow through with these suggestions and amend the Health and Safety in Employment Act to introduce a statutory directors' duty. This is reflected in the Health and Safety (Pike River Implementation)

\footnotetext{
${ }^{74}$ Graham Panckhurst, Stewart Bell and David Henry Royal Commission on the Pike River Coal Mine Tragedy: Volume 2 (October 2012) at 326.

${ }_{76}^{75}$ Health and Safety in Employment Act 1992, s 56.

${ }^{76}$ Panckhurst, Bell and Henry, above n 74, at 326.

${ }^{77}$ Panckhurst, Bell and Henry, above n 74, at 326.

${ }^{78}$ Independent Task Force on Workplace Health and Safety The Report of the Independent Task Force on Workplace Health and Safety: Executive Report (April 2013) at 4.
} 
Bill, ${ }^{79}$ which does not mention anything about directors' duties. This is so, even though such an amendment would bring New Zealand's work health and safety legislation into line with the Australian legislation. Instead, the government issued a set of directors' guidelines on health and safety following the Royal Commission's report, which refers to the due diligence obligations on directors set out in the Australian Work Health and Safety Act $2011^{80}$ and the reasonable steps that directors are required to take to exercise due diligence. ${ }^{81}$ The guidelines state that: ${ }^{82}$

Boards and directors should aspire to move beyond compliance to 'best practice' - an approach that has shown results superior to those achieved by other means and that is used as a benchmark.

The example from the United Kingdom can be contrasted with this example, where the New Zealand government demonstrated that it was not willing to introduce more expansive directors' duties. This example thus indicates that the New Zealand government might be reluctant to impose formal obligations on directors that are more onerous than the obligations directors currently have. Instead, the government seems to prefer that any additional obligations would be only informal and non-binding, that is for example, only in guidelines rather than in legislation. For this reason, Parliament might not be receptive to the idea of enacting legislation to implement a duty to understand tax planning because such a duty imposes more obligations on directors. This duty imposes more obligations because it requires directors to understand more about their companies' matters.

It is therefore unclear exactly how receptive Parliament might be to the idea of enacting legislation to implement a duty to understand tax planning. The fact that the government chose not to implement a directors' duty in relation to work health and safety, despite the position in Australia and the clear recommendations to do so, suggests that the government is also unlikely to implement a directors' duty to

\footnotetext{
${ }^{79}$ Health and Safety (Pike River Implementation) Bill 2013 (130-2).

${ }^{80}$ Work Health and Safety Act 2011 (Australia), s 27(1).

${ }^{81}$ Section 27(5).

${ }^{82}$ Institute of Directors in New Zealand and the Ministry of Business, Innovation and Employment Good Governance Practices Guideline for Managing Health and Safety Risks (May 2013) at 6.
} 
understand tax planning. This conclusion is further supported by the fact that the proposed directors' duty in relation to work health and safety is similar to a duty to understand tax planning because it also sought to impose more onerous obligations on directors.

For these reasons, it is unlikely that a duty to understand tax planning could successfully be implemented in New Zealand law. There are difficulties in trying to include this duty within the existing statutory duties, and there is also limited value to be gained from doing so. Furthermore, it is unlikely that Parliament would enact legislation to create an express statutory duty to understand tax planning. It appears that the New Zealand Parliament is unwilling to expand the scope of directors' duties through legislation, and this is exactly what the legislature would be doing if it created a statutory duty to understand tax planning.

\section{Is it Appropriate to Impose on Directors a Duty to Understand Tax Planning?}

Even if a duty to understand tax planning could be implemented into New Zealand law, it is important to consider whether it is appropriate to impose this duty on directors. This part of the paper evaluates whether it is appropriate to impose on directors a duty to understand tax planning by examining whether this duty is reasonable, whether this duty is comparable to directors' obligations and liability in other areas of regulation, and whether there are already existing mechanisms in place to encourage directors to understand tax planning.

\section{A Is it Reasonable to Expect Directors to Understand their Companies' Tax Planning?}

It is not appropriate to impose on directors a duty to understand their companies' tax planning if it is not reasonable to expect directors to understanding this tax planning. It is not reasonable to expect directors to understand every matter about their companies. Instead, there are some matters that directors will have to rely on professional or expert advice in relation to. These matters might, like tax planning, be important to the company, but are not matters that it is reasonable to expect directors to understand. The reason why it is not reasonable to expect directors to understand these matters might be because it 
would require directors to have more knowledge in the matter than it is reasonable to expect directors to have. For example, it is arguable that it is not reasonable to expect directors to understand the reason why opaque milk bottles keep milk fresher for longer because to expect directors to understand this matter would require directors to have more knowledge in chemistry than it is reasonable to expect directors to have. In addition, if directors were expected to understand these matters, then this expectation would increase the standard as to what is required to be eligible to be appointed as a director, and would consequently reduce the pool of people that are able to be directors.

Nonetheless, it is reasonable to expect directors to understand their companies' tax planning. Directors are usually intelligent, competent and business savvy. Directors are also expected to have a degree of financial literacy and carefully read and understand their companies' financial statements before signing-off, approving, or adopting these financial statements. ${ }^{83}$ These expectations mean that directors should know about basic accounting and financial concepts. Therefore, this description of directors and directors' knowledge demonstrates that directors are smarter and better informed than the average person. For this reason, directors should both have the ability to understand tax planning and the knowledge of basic accounting and financial concepts that will help them to understand this planning. This means that if a tax plan is carefully explained to directors it is reasonable to expect these directors to understand that plan. Even though explaining a tax plan to directors might take a long time, this discussion shows that it is possible to successfully explain a tax plan to directors.

\section{B Is a Duty to Understand Tax Planning Consistent with Directors' Obligations and Liability in Other Areas of Regulation?}

It is also appropriate to impose on directors a duty to understand their companies' tax planning if this duty is consistent with directors' obligations and liability in other areas of regulation. This part evaluates whether a duty to understand tax planning is consistent with directors' obligations and liability in other areas of regulation by looking at whether the nature of this duty is consistent with the nature

\footnotetext{
${ }^{83}$ Australian Securities and Investments Commission v Healey [2011] FCA 717, 196 FCR
} 291 [Centro] at [15]. 
of the existing statutory directors' duties, whether the directors' liability for breaching this duty is consistent with the directors' liability in other areas of regulation, and finally whether the size of the liability for breaching this duty is consistent with the size of the liability for breaching other obligations.

\section{Is the nature of this duty consistent with the nature of the existing statutory directors' duties?}

Directors' duties recognise that in some situations the directors' interests may diverge from their companies' interests. ${ }^{84}$ For example, the directors' and companies' interests may diverge when directors act with insufficient care or diligence in relation to the company's business operations. ${ }^{85}$ Therefore, the purpose of directors' duties is to align the directors' actions with their companies' interests. ${ }^{86}$ For example, the purpose of the director's duty of care in s 137 is to ensure that directors act with the level of care, diligence and skill that is in their companies' interests.

The directors' and companies' interests may also diverge when directors' do not understand their companies' tax planning. It might not be in the directors' interests to understand their companies' tax planning because it could take a long time to understand this tax planning, particularly if this tax planning is complicated. Instead, the directors might consider that it is in their interests to focus on something else and instead rely on external or professional advisers to understand this tax planning for them. It might, however, be in the companies' interests that directors' understand their companies' tax planning because it would help directors to make better informed decisions about their companies' tax planning. Moreover, it would help directors to make decisions about their companies' tax planning that balance their companies' interests to minimise their tax obligations against their companies' interests to reduce the risk that the IRD will challenge their tax positions, in a manner that is consistent with how their companies would balance each of these interests. Thus, the purpose of the duty to understand tax planning is to ensure that directors act in their companies' interests by

\footnotetext{
${ }^{84}$ Walker and Others Commercial Applications of Company Law in New Zealand (4th ed, $\mathrm{CCH}$, Auckland, 2012) at [1202].

${ }^{85}$ At [1202].

${ }^{86}$ At [1202].
} 
understanding their companies' tax planning. This purpose is consistent with the purpose of directors' duties generally.

Directors are required to understand various matters about their companies. For example, the Federal Court of Australia in Australian Securities and Investments Commission v Healey (Centro) held that directors are required to carefully read and understand their companies' financial statements before exercising their responsibility to sign-off, approve, or adopt these statements. ${ }^{87}$ Also, Heath $\mathrm{J}$ in Nathans Finance held that it is "axiomatic that a director of a finance company will be assumed to have the ability to read and understand financial statements and the way in which assets and liabilities are classified." 88 His Honour then noted that this requirement "represent[s] no more than the basic level of understanding needed to run a finance company." 89 Furthermore, in Australia, directors and officers have a duty to exercise due diligence to ensure that their companies comply with any statutory duties or obligations they have under the Work Health and Safety Act. ${ }^{90}$ Due diligence includes taking reasonable steps to acquire and keep up-to-date knowledge of work health and safety matters, and to gain an understanding of the nature of the operations of the business or undertaking of the person conducting the business or undertaking and generally of the hazards and risks associated with those operations. ${ }^{91}$ These examples demonstrate that the duty to understand tax planning, which also requires directors to understand another matter about their companies (that is, their companies' tax planning), is consistent what is already required of directors.

This conclusion is supported by the fact that directors are in some situations also required to understand their companies' financial affairs. $^{92}$ The company's tax planning relates to the company's financial affairs. Specifically, the company's tax planning involves arranging the company's financial affairs so as to minimise the company's tax obligation. Furthermore, the company's tax planning influences the financial information in the company's financial statements and is ultimately represented in these financial statements

${ }^{87}$ Centro, above n 83, at [15].

${ }^{88}$ Nathans Finance, above n 71, at [83].

${ }^{89}$ At [87].

${ }^{90}$ Work Health and Safety Act (Australia), s 27(1).

${ }_{91}^{91}$ Work Health and Safety Act (Australia), s 27(5).

92 Davidson, above n 39, at [121]. 
as the company's tax expense. Finally, the company's tax planning and financial planning both use similar accounting and financial concepts (for example, income and expenditure). This relationship thus demonstrates that there is not a big jump between requiring directors to understand their companies' financial affairs and requiring directors to understand their companies' tax planning. For this reason, requiring directors to understand their companies' tax planning is not wholly out of line with what is already required of directors.

2 Is the liability imposed on directors for breaching this duty is consistent with the liability imposed on directors in other areas of regulation?

There are other areas of regulation, outside of tax law, that also impose obligations on directors, or alternatively, liability on directors for their companies' actions. It is arguable that it is appropriate to impose on directors a duty to understand tax planning if the liability imposed on directors for breaching this duty is consistent with the liability imposed on directors in other areas of regulation. This paper looks at four other areas of regulation, namely: fair trading; competition; resource management; and work health and safety law. The starting point for comparing these obligations is that if directors breach a duty to understand tax planning they can become personally liable for any shortfall penalties imposed by the IRD on the directors' companies. These shortfall penalties are of a civil nature. The fact that shortfall penalties are of a civil nature is material because it means that directors can become personally liable for penalties that only need to meet a relatively lower standard of proof to be imposed, than penalties of a criminal nature, which must meet a higher standard of proof to be imposed.

(a) Tax law

Before looking at other areas of regulation, there are also other obligations imposed on directors under tax law. For example, in Australia, directors are responsible for ensuring that their companies meet their pay as you go withholding and superannuation guarantee charge obligations. A director that fails to meet a pay as you go withholding ${ }^{93}$ or superannuation guarantee charge ${ }^{94}$ liability in full by

\footnotetext{
${ }^{93}$ Tax Assessment Act 1953 (Australia), sch 1, s 18-125.

${ }^{94}$ Schedule 1, s 269-20.
} 
the due date automatically becomes personally liable for a penalty equal to the unpaid amount. This example demonstrates that directors already owe obligations in regard to their companies' tax affairs. This example thus suggests that a duty to understand tax planning, which also imposes obligations on directors in regard to their companies' tax affairs, is consistent with the obligations that directors already owe. However, it is arguable that these obligations can be distinguished. The reason for a duty to understand tax planning is to ensure that directors understand their companies' tax planning. In contrast, the reason for the directors' responsibility to ensure that their companies meet their pay as you go withholding and superannuation guarantee charge obligations is to reduce the scope for companies to escape liabilities and payments of employee entitlements. ${ }^{95}$ The Australian Tax Office noted in its decision to impose penalties on superannuation guarantee charge obligations, in addition to pay as you go obligations, that: ${ }^{96}$

Extending the director penalty regime to apply to unpaid super guarantee charge better secures workers' entitlements. A director penalty can now arise from amounts of unpaid super guarantee charge that should have been paid to a super fund for the benefit of the employee.

This statement reveals that the directors' responsibility to ensure that their companies meet their pay as you go withholding and superannuation guarantee charge obligations focuses on a narrow and specific issue: ensuring that companies' pay employee entitlements. For this reason, it is equally arguable that a duty to understand tax planning is different to the directors' responsibility to ensure that their companies meet their pay as you go withholding and superannuation guarantee charge obligations. The fact that these obligations can be distinguished thus means that it is difficult to successfully establish that the duty to understand tax planning is consistent with the other obligations that directors owe in regard to their companies' tax affairs.

(b) Fair trading law

In New Zealand, the Fair Trading Act 1986 prohibits persons, in trade, from engaging in conduct that is misleading or deceptive or is likely

95 Australian Tax Office "Strengthening director-obligations" (media statement, 12 August 2013).

${ }^{96}$ Australian Tax Office, above n 95. 
to mislead or deceive. ${ }^{97}$ The majority in the Court of Appeal in Body Corporate $v$ Taylor held that liability under this section could extend to a person who was not in trade directly on his or her own account, but rather was acting as a director or senior employee of the company that was in trade. ${ }^{98}$ This means that directors of a company that engages in misleading or deceptive conduct in relation to trade could become personally liable for breaches of the Fair Trading Act. Glazebrook and Ellen France JJ, however, disagreed with the majority and found that, ordinarily, people who are not themselves in trade are not liable under the Fair Trading Act, unless they knowingly aid and abet infringements. ${ }^{99}$

The liability that can be imposed on directors under the Fair Trading Act is similar to the liability that can be imposed on directors under a duty to understand tax planning. The liability that can be imposed under these obligations is similar because they are both of a civil nature. That is, a breach of either obligation gives rise to civil, not criminal, remedies. A breach of $\mathrm{s} 9$, which prohibits persons in trade from engaging in misleading or deceptive conduct, is not a criminal offence within s 40 of the Fair Trading Act, and therefore does not give rise to a criminal sanction. Instead, a breach of this section gives rise to wide-ranging civil remedies under ss 41,42 and 43 of the Fair Trading Act. ${ }^{100}$ These civil remedies include injunctions granted by the court ${ }^{101}$ and orders to disclose information or publish advertisements. ${ }^{102}$ Similarly, the shortfall penalties that directors can become personally liable for if they breach a duty to understand tax planning are civil, not criminal, penalties. ${ }^{103}$ This similarity demonstrates that the liability imposed on directors under a duty to understand tax planning is consistent with the liability that is imposed on directors under fair trading law.

(c) Competition law

Directors may face consequences when their companies' breach competition law. However, these consequences differ depending on

\footnotetext{
${ }^{97}$ Fair Trading Act 1986, s 9.

${ }^{98}$ Body Corporate 202254 v Taylor [2008] NZCA 317, [2009] 2 NZLR 17 at [74] and [78].

${ }^{99}$ At [101].

100 Thomas Gault (ed) Gault on Commercial Law (online looseleaf ed, Brookers) at [FTA9.02].

${ }^{101}$ Fair Trading Act, s 41.

102 Section 42.

${ }^{103}$ Tax Administration Act 1994 (New Zealand), s 141.
} 
the jurisdiction in which the breach of competition law occurs. In the United Kingdom, firms may face a financial penalty of up to 10 per cent $^{104}$ of their worldwide turnover for breaching competition law. ${ }^{105}$ Directors, however, cannot become personally liable for these penalties. The United Kingdom Court of Appeal in Safeway Stores Ltd $v$ Twigger held that a company could not recover from its directors penalties imposed on the company for breaching competition law. ${ }^{106}$ In this case, Safeway, a supermarket chain, had admitted its own participation in a cartel, and wanted to recover the $€ 10,700,000$ penalty imposed on it by the Office of Fair Trading from 11 of its former directors and employees who were alleged to have been responsible for getting it into the cartel in the first place. ${ }^{107}$ Instead, a director can be disqualified from being a director under a Competition Disqualification Order if the court is satisfied that his or her company has committed a breach of competition law and the director's conduct in connection with that infringement makes him unfit to be concerned in the management of a company. ${ }^{108}$

In Australia, a person that suffers loss or damage as a result of a contravention of certain provisions in the Competition and Consumer Act 2010 (which prohibits various anti-competitive practices) may recover that loss or damage from the directors of a company, but only if the directors were involved in the contravention. ${ }^{109}$ Directors are involved in the contravention if they have intentionally participated in the contravention. ${ }^{110}$ This means that they must have: aided, abetted, counselled or procured the contravention; induced, whether by threats or promises or otherwise, the contravention; been in any way, directly or indirectly, knowingly concerned in, or party to, the contravention; or have conspired with others to effect the contravention. ${ }^{111}$ For example, the Federal Court of Australia in Norcast $v$ Bradken Limited (No. 2) held that Bradken Ltd and two of its directors were liable for damages of USD 22,400,000, pre-judgment interest of USD

\footnotetext{
${ }^{104}$ Calcualted in accordance with the Competition Act 1998 (Determination of Turnover for Penalties) Order 2000 (UK).

${ }^{105}$ Competition Act 1998 (UK), s 36.

${ }^{106}$ Safeway Stores Ltd \& Ors v Twigger \& Ors [2010] EWCA CIv 1472, [2011] 1 C.L.C. 80 at [38].

${ }^{107}$ At [1].

${ }^{108}$ Company Directors Disqualification Act 1986 (UK), s 9A.

${ }^{109}$ Competition and Consumer Act 2010 (Australia), s 76.

${ }^{110}$ Norcast $v$ Bradken Limited (No.2) [2013] FCA 235, 2013 WL 1190706 at [269].

${ }^{111}$ Competition and Consumer Act 2010, s 75B.
} 
2,940,690.41 and post-judgment interest and costs, ${ }^{112}$ for their involvement in cartel conduct and misleading and deceptive conduct. $^{113}$

Finally, in New Zealand, the court may impose a pecuniary penalty on an individual who has either: contravened any of the provisions of Part 2 of the Commerce Act 1986 (which regulates restrictive trade practices); attempted to contravene such a provision; aided, abetted, counselled, or procured any other person to contravene such a provision; induced, or attempted to induce, any other person, whether by threats or promises or otherwise, to contravene such a provision; been in any way, directly or indirectly, knowingly concerned in, or party to, the contravention by any other person of such a provision; or conspired with any other person to contravene such a provision, unless the court considers that there is good reason for not doing so. ${ }^{114}$ Mallon and Stevens suggested that possible good reasons for not imposing a penalty could be if the offending was not deliberate, the individual took and followed legal advice before acting, or the individual played only a minor role in the prohibited conduct. ${ }^{115}$ The maximum pecuniary penalty for an individual is NZD 500,000. ${ }^{116}$ The standard of proof required to establish liability for this penalty is the civil standard. ${ }^{117}$ The court may also make an order that a person not be concerned with or take part in the management of a body corporate for a period not exceeding five years if the court is satisfied that the person has engaged in price fixing or is giving effect to or entering into an exclusionary provision. ${ }^{118}$

There is no consistent approach to directors' liability across jurisdictions. In Australia, directors can become personally liable for the loss or damage that results from their companies' breach of competition law. However, in the United Kingdom, directors cannot become personally liable for any penalties imposed on their companies for breaching competition law, and in New Zealand, directors can only become liable for a civil penalty for being involved in the breach of competition law. Despite this, there are similarities

\footnotetext{
${ }^{112}$ Norcast $v$ Bradken Limited (No.3) [2013] FCA 283, 2013 WL 1342396 at [11] and [12].

${ }^{113}$ Norcast $v$ Bradken Limited (No.2), above n 110.

${ }^{114}$ Commerce Act, s 80(2).

115 J Mallon and J Stevens "Commerce Act penalties for individuals" [2001] NZLJ 339 at 340.

${ }^{116}$ Commerce Act, s 80(2B).

${ }^{117}$ Brookers, above $\mathrm{n} 46$, at [CA80.01].

${ }^{118}$ Commerce Act, s 80C.
} 
between the approach to directors' liability under a duty to understand tax planning and the approaches to directors' liability under competition law. First, New Zealand's approach is similar because it permits directors to become personally liable for civil penalties. Australia's approach is also similar because it permits directors to become personally liable for loss or damage that their companies would otherwise be liable for. In addition, it has been noted that the focus under New Zealand competition law is on penalising individuals within a firm who are responsible for making the decisions that lead to conduct in breach of the Commerce Act. ${ }^{119}$ The focus under a duty to understand tax planning is similar. That is, the focus under this duty is on penalising directors who are responsible for making decisions about their companies' tax planning which lead to tax positions that incur shortfall penalties, if they do not understand this tax planning. Therefore, it is arguable that because of the similarities between the approach to directors' liability under a duty to understand tax planning and the approaches to directors' liability under competition law, the liability imposed on directors under a duty to understand tax planning is consistent with the liability imposed on directors under competition law.

However, there are also differences between the approach to directors' liability under a duty to understand tax planning and the approaches to directors' liability under competition law that undermine the persuasiveness of this argument. First, the director's liability under New Zealand competition law is in addition to any penalties that are imposed on the director's company for breaching competition law. Similarly, the director's liability under Australian competition law sits alongside the director's company's liability for the breach of competition law. This is illustrated in Norcast $v$ Bradken, where both Bradken Ltd and two of its directors were held liable together for damages of USD 22,400,00 plus interests and $\operatorname{costs}^{120}$ for breaching competition law. This means that both the company and the company's directors can be liable for the same conduct that breached competition law. In contrast, the director's liability for shortfall penalties for breaching the duty to understand tax planning is in replacement of the company's liability for these penalties. That is, the directors, if they breach this duty, are liable for

$119 \mathrm{~J}$ Mallon and J Stevens, above n 115, at 340.

${ }^{120}$ Norcast v Bradken Limited (No.3), above n 112, at [11] and [12]. 
these shortfall penalties instead of their companies. This difference thus undermines the argument that the liability imposed on directors under a duty to understand tax planning is consistent with the liability imposed on directors under competition law.

The further difficulty with this is argument is the fact that the United Kingdom Court of Appeal's decision in Safeway Stores $v$ Twigger appears to rejects the very thing that a breach of a duty to understand tax planning would permit, that is, that a company could recover from its directors a civil penalty imposed on the company. In this case, the Court of Appeal rejected the argument that Safeway could recover from its directors the penalty imposed on the company for breaching competition law. ${ }^{121}$ This case, therefore, suggests that the liability imposed on directors under a duty to understand tax planning is not consistent with the liability that is imposed on directors under competition law. It may, however, be possible to distinguish this case from the directors' liability under a duty to understand tax planning. Pill L.J. noted that the policy of the Competition Act 1998 is to protect the public, and this policy would be undermined if firms were able to pass on the liability to their employees, or the employees' directors and officers' insurers. ${ }^{122}$ That is, the public would only be protected if the firm itself bears the responsibility and consequence for breaching the Competition Act. ${ }^{123}$ In contrast, the imposition of personal liability on directors for the company's shortfall penalties for breaching a duty to understand tax planning is for the benefit of the directors' companies, and not to protect the public. Therefore, there is no similar policy reason for ensuring that the company itself bears the liability for these penalties.

This examination of some of the approaches to directors' liability under competition law reveals that it is not clear whether the liability imposed on directors under a duty to understand tax planning is consistent with the liability imposed on directors under competition law. Australian and New Zealand competition law permits directors to become personally liable, in some manner, for breaches of competition law, but this liability sits alongside the director's company's liability for these breaches, not in replacement of this liability. This is inconsistent with the nature of the directors' liability

\footnotetext{
${ }^{121}$ Safeway, above n 106, at [38].

${ }^{122}$ At [44].

${ }^{123}$ At [44].
} 
under a duty to understand tax planning. Furthermore, United Kingdom competition law does not permit companies to recover from their directors any civil penalties imposed on the company. Thus, United Kingdom competition law is also inconsistent with a duty to understand tax planning because it rejects the very thing that a duty to understand tax planning would permit. However, the fact that the reasoning for the decision in Safeway Stores $v$ Twigger does not apply to the duty to understand tax planning means that it is possible to argue that this rejection should not apply outside of a competition law context.

For these reasons, although not one of the approaches to directors' liability under competition law provides an exact analogy to the approach to directors' liability under a duty to understand tax planning, these approaches share some similarities with the approach to directors' liability under a duty to understand tax planning. These similarities therefore suggest that the liability imposed on directors under a duty to understand tax planning is not wholly out of line with the liability imposed on directors under competition law.

(d) Resource management law

In New Zealand, where a company is convicted of an offence under the Resource Management Act 1991, the company's directors and management might also be convicted of that offence, if it can be shown that that the offence took place with their authority or consent and they knew or should have known of the offence but failed to take all reasonable steps to stop it. ${ }^{124}$ For example, in $R v$ Kiwi Drilling Co Ltd and Smith (Kiwi Drilling) the company's director was initially fined NZD 53,000, but this fine was reduced on appeal to NZD $15,000 .^{125}$

The liability that can be imposed on directors under a duty to understand tax planning is different to the liability that can be imposed on directors under the Resource Management Act. The director's liability for shortfall penalties under a duty to understand tax planning is in replacement of the company's liability for these penalties. In contrast, the director's liability in relation to the offence under the Resource Management Act is in addition to the company's liability for that offence. This difference demonstrates that the liability imposed

\footnotetext{
${ }^{124}$ Resource Management Act 1991, s 340(3).

${ }^{125} R$ v Kiwi Drilling Co Ltd and Smith (1997) 4 ELRNZ 23 [Kiwi Drilling] at 8.
} 
on directors under a duty to understand tax planning is not consistent with the liability that is imposed on directors under resource management law.

(e) Work health and safety law

In Australia, directors and officers have a duty to exercise due diligence to ensure that their companies comply with any statutory duties or obligations they have under the Work Health and Safety Act. $^{126}$ Directors may face criminal penalties for breaching this duty. ${ }^{127}$ Due diligence includes taking reasonable steps to acquire and keep up-to-date knowledge of work health and safety matters, and to gain an understanding of the nature of the operations of the business or undertaking of the person conducting the business or undertaking and generally of the hazards and risks associated with those operations. $^{128}$

In New Zealand, directors have no express duties under the Health and Safety in Employment Act. Rather, where a body corporate fails to comply with a provision of the Act, any of its officers, directors, or agents who directed, authorised, assented to, acquiesced in, or participated in, the failure is a party to and guilty of the failure and is liable on conviction to the punishment provided for the offence, whether or not the body corporate has been prosecuted or convicted. $^{129}$ Where the Health and Safety in Employment Act is breached and serious harm is caused, a fine not exceeding NZD 50,000 may be imposed on directors. ${ }^{130}$ In other situations, fines of up to NZD 25,000 may be imposed. ${ }^{131}$ Furthermore, the government has issued a set of directors' guidelines on health and safety, which refer to the due diligence obligations on directors in the Australian Work Health and Safety Act and the reasonable steps that directors are required to take to exercise due diligence. ${ }^{132}$

The directors' duty to exercise due diligence in Australian law is similar to a duty to understand tax planning because it also imposes penalties on directors for failing to understand something about the

\footnotetext{
${ }^{126}$ Work Health and Safety Act 2011 (Australia), s 27(1).

${ }^{127}$ Sections 31 and 32 .

${ }^{128}$ Section 27(5).

${ }^{129}$ Health and Safety in Employment Act 1992, s 56.

${ }^{130}$ Health and Safety in Employment Act, s 49.

${ }^{131}$ Section 50.

132 Institute of Directors in New Zealand and the Ministry of Business, Innovation and Employment, above n 82, at 6.
} 
company. Specifically, under this duty to exercise due diligence directors could be liable to penalties for failing to exercise due diligence by failing to gain an understanding of the hazards and risks associated with their companies' operations. Nonetheless, the liability that can be imposed on directors under both Australian and New Zealand work health and safety law is also different to the liability that can be imposed on directors under a duty to understand tax planning because the penalties that can be imposed on directors under these laws are of a criminal, rather than civil, nature. This difference demonstrates that the liability imposed on directors under a duty to understand tax planning is not consistent with the liability that is imposed on directors under work health and safety law.

\section{(f) Conclusion}

The examination of the obligations and liability imposed on directors under other areas of regulation reveals that there is not one example of an obligation or liability imposed on directors under these other areas of regulation that provides an exact analogy to the liability imposed on directors under a duty to understand tax planning. Instead, this examination reveals that there are several similarities between the liability under a duty to understand tax planning and the obligations and liability imposed on directors under other areas of regulation. For example, under work health and safety law directors can become liable for failing to understand something about the company. In addition, under fair trading and competition law directors can become liable for civil penalties. These similarities illustrate that even though the exact nature of the liability imposed on directors under a duty to understand tax planning is unique, the nature of this liability is not wholly out of line with the liability imposed on directors under other areas of regulation. For this reason, it is arguable that in a general sense the liability imposed on directors for breaching the duty to understand tax planning is consistent with the liability imposed on directors in other areas of regulation. This argument thus supports the conclusion that it is appropriate to impose on directors a duty to understand their companies' tax planning 
3 Is the size of the directors' liability for breaching a duty to understand tax planning consistent with the size of the

directors' liability for breaching other obligations?

If a director has breached the duty to understand tax planning, then that director can become personally liable for any shortfall penalties imposed on the director's company by the IRD. These shortfall penalties might in some situations be substantial in size. For example, in the Westpac case, the Commissioner of Inland Revenue held that the purpose or effect of Westpac's transactions, or parts of these transactions, was tax avoidance, and assessed Westpac's liability at NZD 586,000,000, before any penalties applied. ${ }^{133}$ The penalty payable for taking an abusive tax position is 100 per cent of the resulting tax shortfall. ${ }^{134}$ Therefore, if the Commissioner held that Westpac had taken an abusive tax position, then the size of the shortfall penalty that the Commissioner could impose in this case is NZD 586,000,000. This appears to be a very large penalty to make directors personally liable for. However, it is arguable that it is appropriate to make directors personally liable for these penalties if the size of this liability is consistent with the size of liabilities that directors might be able to become personally liable for under other areas of regulation.

The difficulty with making this argument is that there are no examples of cases or statutes where directors could become personally liable for an amount that is comparable to the size of the shortfall penalties that directors could become personally liable for under a duty to understand tax planning. For example, in the Commerce Act the maximum pecuniary penalty for an individual who breaches a provision in the Act is NZD 500,000. ${ }^{135}$ Also, in Kiwi Drilling the company's director was fined only NZD 53,000 for breaches of the Resource Management Act, and this was reduced on appeal to NZD 15,000. ${ }^{136}$ The most comparable example is Norcast $v$ Bradken. In this case, the Federal Court of Australia held that Bradken Ltd and two of its directors were liable for damages of USD 22,400,000 million plus interest and costs for breaching competition law. ${ }^{137}$ However, both the company and its directors were liable together for

${ }^{133}$ Westpac, above n 22, at [2].

${ }^{134}$ Tax Administration Act, s 141D(3).

${ }^{135}$ Commerce Act, s 80(2B).

${ }^{136}$ Kiwi Drilling, above $\mathrm{n} 125$, at 8.

${ }^{137}$ Norcast v Bradken Limited (No.3), above n 120, at [11] and [12]. 
this amount, and moreover, the size of this liability is still considerably smaller than the size of the shortfall penalties that directors could potentially become personally liable for under a duty to understand tax planning.

Thus, the substantial difference between the size of the liability that might be imposed on directors for breaching a duty to understand tax planning and the size of the liability that might be imposed on directors for breaching other obligations demonstrates that these liabilities are not consistent. For this reason, it is arguable that it is not appropriate to impose on directors a duty to understand their companies' tax planning, because to do so could potentially make directors personally liable for any shortfall penalties imposed on the company, and to make directors personally liable for these penalties would be excessive and wholly out of line with the size of the liabilities that can currently be imposed on directors.

\section{Are there Mechanisms in Place to Ensure that Directors Understand their Companies' Tax Planning?}

It is not necessary to impose on directors a duty to understand their companies' tax planning if the existing mechanisms in place to make directors accountable to their companies for their actions are sufficient to ensure that directors understand their companies' tax planning.

One example of an informal mechanism that makes directors accountable to their companies for their actions is director resignation. There have been several examples of directors resigning from their positions following their involvement in an incident that has harmed their companies' reputation or financial performance. For example, the managing director of Fonterra's New Zealand manufacturing operations resigned following the botulism bacteria scare. ${ }^{138}$ This scare involved a potentially contaminated whey protein ingredient sold by Fonterra for use in baby formula, sports drinks, and animal foods. ${ }^{139}$ Similarly, both the chief executive officer and chairman of Barclays Bank’s resigned following the $£ 290,000,000$ fine imposed on Barclays by the United Kingdom and United States authorities for

\footnotetext{
${ }^{138}$ Fonterra "Managing Director of Fonterra NZ Milk Products Resigns" (media release, 14 August 2013).

${ }^{139}$ Christopher Adams and Nick Perry "Botulism scare: Mass recall of NZ dairy" The New Zealand Herald (online ed, Auckland, 4 August 2013).
} 
trying to fix a key inter-bank interest rate. ${ }^{140}$ These examples demonstrate that resignation is one possible mechanism to make directors personally responsible for their actions, or conversely, their lack of actions. There are, however, no similar examples of directors resigning from their positions in the context of company tax planning. For example, not one of the directors of Westpac or BNZ resigned following the Westpac and BNZ tax avoidance cases, despite the fact that these cases resulted in significant financial consequences for these banks. In BNZ Investments Ltd v Commissioner of Inland Revenue approximately NZD 416,000,000 of tax hinged on the outcome of the proceedings, ${ }^{141}$ and in the Westpac case the total amount of tax at issue was NZD 961,000,000. ${ }^{142}$

Therefore, it is arguable that the existing mechanisms in place are not sufficient to make directors accountable for their companies' tax planning. The corollary of this argument is that these mechanisms are not able to ensure that directors understand their companies' tax planning. For this reason, it necessary to impose on directors a duty to understand their companies' tax planning to ensure that directors understand this tax planning.

\section{Conclusion}

This paper focused on whether the commentary outlining what is expected of directors in regard to their companies' tax planning both could and should be translated into obligations on the part of directors in regard to their companies' tax planning.

It is clear that directors should have a duty to understand their companies' tax planning. The difficulty, however, is whether this duty could be implemented into New Zealand law. This paper focused on two possible avenues for implementing this duty into law. There are many reasons to indicate that this duty could fit within the existing directors' duties in ss 131 and 137 of the Companies Act. The problem, however, is that there is limited value to be gained from fitting a duty to understand tax planning within these existing directors' duties because they are generally only enforced when the company is insolvent, and it is possible that a director might breach a

140 "Barclays boss Bob Diamond resigns amid Libor scandal" $B B C$ (online ed, London, 3 July 2012)

${ }^{141}$ BNZ Investments Ltd v Commissioner of Inland Revenue (2009) 24 NZTC 23,582 (HC) at

${ }^{[9]}$. Westpac, above n 22, at [2] 
duty to understand tax planning when the company is not insolvent. This would mean that there might be situations where the duty is breached, but the breach is not enforced. Moreover, is also unlikely that the New Zealand Parliament would enact legislation to implement a separate duty to understand tax planning. To enact legislation to implement a separate duty would address the problem with fitting the duty to understand tax planning within the existing directors' duties. However, the fact that the government was not willing to enact legislation to create additional directors' duties in relation to work health and safety indicates that Parliament would be unlikely to enact legislation in this situation. Therefore, it is unlikely that a duty to understand tax planning could successfully be implemented into law in New Zealand. This outcome might be different in other jurisdictions. For example, both the United Kingdom and Australia have been more willing to enact legislation to create more onerous directors' duties. This is illustrated in the enactment of the United Kingdom Companies Act 2006 and the Australian Work Health and Safety Act 2011. These examples suggest that it is more likely that the United Kingdom and Australia would enact legislation to implement a duty to understand tax planning.

Even if, a duty to understand tax planning could be implemented into law, it is not clear whether it is appropriate to impose such a duty on directors. It is reasonable to expect directors to understand tax planning because directors are equipped with both the ability and the knowledge to be able to understand tax planning. Moreover, the nature of a duty to understand tax planning is consistent with the nature of the existing statutory directors' duties. This paper then compared this duty to directors' obligations and liability under other areas of regulation. There are no examples of directors' obligations and liability under other areas of regulation that provide an exact analogy to a duty to understand tax planning. Notwithstanding, these examples share some similarities with a duty to understand tax planning, and therefore indicate that a duty to understand tax planning is not out of line with existing directors' obligations and liabilities. For this reason, this comparison suggests that it is appropriate to impose on directors a duty to understand tax planning. The problem, however, is that the shortfall penalties that directors can become personally liable for under a duty to understand tax planning might in some situations be considerably greater in size than the liabilities that 
directors can become personally liable for under other areas of regulation. This difference suggests that it is not appropriate to impose on directors a duty to understand tax planning. Finally, the fact that the existing mechanisms in place to make directors accountable to their companies for their actions are not sufficient to ensure that directors understand their companies' tax planning suggests that it is necessary to impose a duty on directors a duty to understand tax planning.

This examination suggests that although in most respects it is appropriate to impose on directors a duty to understand tax planning, it might not in some situations be appropriate to make directors personally liable for the total sum of the shortfall penalties. In these situations, it might instead be more appropriate to make directors personally liable for a contribution towards the shortfall penalties. To require directors to contribute to their companies' shortfall penalties is also consistent with the nature of the director's personal liability for breaches of the directors' duties in the Companies Act.

This paper thus demonstrates that although it is clear that directors should understand their companies' tax planning, it is difficult to implement a legal duty that effectively ensures that directors understand their companies tax planning. 


\section{Bibliography}

\section{Cases}

New Zealand

BNZ Investments Ltd v Commissioner of Inland Revenue (2009) 24 NZTC 23,582 (HC).

Body Corporate 202254 v Taylor [2008] NZCA 317, [2009] 2 NZLR.

Challenge Corporation Limited $v$ Commissioner of Inland Revenue (1984) 6 NZTC 62,808 (HC).

Challenge Corporation Ltd v Commissioner of Inland Revenue [1986]

2 NZLR 513 (PC).

Davidson v Registrar of Companies [2011] 1 NZLR 542 (HC).

Fatupaito v Bates [2001] 3 NZLR 386.

Mangin v Comissioner of Inland Revenue [1971] NZLR 591 (PC).

Ministry of Economic Development v Feeney (2010) 10 NZCLC 264,715 [Feltex].

Nippon Express (New Zealand) Ltd v Woodward \& Hutt (1998) 8 NZCLC 261,765.

$R$ v Kiwi Drilling Co Ltd and Smith (1997) 4 ELRNZ 23 [Kiwi Drilling].

$R v$ Moses HC Auckland CRI-2009-004-1388, 8 July 2011 [Nathans Finance].

Re Cellar House Ltd (in liquidation) (2009) 15 NZBLQ 3.

Westpac Banking Corporation Ltd v Commissioner of Inland Revenue [2008] 2 NZLR 709 (HC).

Australia

Australian Securities and Investments Commission v Healey [2011] FCA 717, 196 FCR 291 [Centro].

Daniels $v$ AWA Ltd (1995) 37 NSWLR 438 (CA).

Norcast $v$ Bradken Limited (No.2) [2013] FCA 235, 2013 WL

1190706.

Norcast $v$ Bradken Limited (No.3) [2013] FCA 283, 2013 WL

1342396.

United Kingdom

Safeway Stores Ltd \& Ors v Twigger \& Ors [2010] EWCA CIv 1472, [2011] 1 C.L.C. 80.

\section{Legislation}

New Zealand

Companies Act 1993.

Fair Trading Act 1986.

Financial Reporting Act 1993.

Health and Safety in Employment Act 1992.

Income Tax Act 2007.

Resource Management Act 1991.

Tax Administration Act 1994. 
Australia

Competition and Consumer Act 2010 (Australia).

Tax Assessment Act 1953 (Australia).

Work Health and Safety Act 2011 (Australia).

United Kingdom

Companies Act 2006 (UK).

Company Directors Disqualification Act 1986 (UK).

Competition Act 1998 (UK).

Competition Act 1998 (Determination of Turnover for Penalties)

Order 2000 (UK).

\section{Books}

Jeffrey Owens "Good Corporate Governance: The Tax Dimension" in Wolfgang Schon (ed) Tax and Corporate Governance (Springer, 2008) 9.

Kevin Holmes The Concept of Income: A multi-disciplinary analysis (IBFD Publications, Amsterdam, 2001).

Walker and Others Commercial Applications of Company Law in New Zealand (4th ed, CCH, Auckland, 2012) at [1202].

\section{Journal articles}

John Prebble "Ectopia, Formalism, and Anti-Avoidance Rules in Income Tax Law" in W. Krawietz and others (eds) Prescriptive Formality and Normative Rationality in Modern Legal Systems (Duncker and Humblot, 1994) 367.

John Prebble "Ectopia, Tax Law and International Taxation" (1997) 5 B.T.R. 383.

Judith Freedman and others "Corporate Tax Risk and Tax Avoidance: New Approaches" (2009) 1 B.T.R. 74.

J Mallon and J Stevens "Commerce Act penalties for individuals" [2001] NZLJ 339.

\section{Parliamentary and government materials}

Health and Safety (Pike River Implementation) Bill 2013 (130-2).

Inland Revenue Department Compliance Focus 2010-2011 (August 2010).

Inland Revenue Department Taxpayer obligations, interest and penalties (IR40, April 2013).

Institute of Directors in New Zealand and the Ministry of Business, Innovation and Employment Good Governance Practices Guideline for Managing Health and Safety Risks (May 2013).

\section{Reports}

Graham Panckhurst, Stewart Bell and David Henry Royal Commission on the Pike River Coal Mine Tragedy: Volume 2 (October 2012). 
Independent Task Force on Workplace Health and Safety The Report of the Independent Task Force on Workplace Health and Safety: Executive Report (April 2013).

OECD Forum on tax administration - Information Note, General Administrative Principles: Corporate governance and tax risk management (July 2009).

\section{Internet resources}

Andrew Beck and others Morison's Company Law (looseleaf ed, LexisNexis).

"Barclays boss Bob Diamond resigns amid Libor scandal" $B B C$ (online ed, London, 3 July 2012).

Brookers Company Law (online looseleaf ed, Thomson Reuters).

Christopher Adams and Nick Perry "Botulism scare: Mass recall of NZ dairy" The New Zealand Herald (online ed, Auckland, 4 August 2013).

Fonterra "Managing Director of Fonterra NZ Milk Products Resigns" (media release, 14 August 2013).

Kamal Ahmed "Starbucks pays first tax since 2008" The Telegraph (online ed, Kent, 22 June 2013).

Niko Kloeten "Westpac loses $\$ 900$ million tax avoidance case" The National Business Review (Online ed, New Zealand, 8 October 2009).

Terry Macalister "Starbucks pays corporation tax in UK for first time in five years" The Guardian (online ed, London, 23 June 2013).

Thomas Gault (ed) Gault on Commercial Law (online looseleaf ed, Brookers).

\section{Other resources}

Australian Tax Office "Strengthening director-obligations" (media statement, 12 August 2013).

David Patterson "Tax Governance - Practitioners advising Boards and Audit and Risk Sub-Committees" (paper presented to New Zealand Law Society - Tax Conference, September 2011) 65.

Michael D'Ascenzo, Commissioner of Taxation "What's tax got to do with it?" (speech to the Australian Institute of Company Directors, Sydney, 16 February, 2010). 